\title{
Economic and political inclusion in human development conditional income transfer programmes in Latin America
}

DOI:

$10.1017 / \mathrm{S} 1474746416000075$

\section{Document Version}

Accepted author manuscript

Link to publication record in Manchester Research Explorer

\section{Citation for published version (APA):}

Barrientos, A., \& Villa, J. (2016). Economic and political inclusion in human development conditional income transfer programmes in Latin America. Social Policy and Society, 15(3), 421-433.

https://doi.org/10.1017/S1474746416000075

\section{Published in:}

Social Policy and Society

\section{Citing this paper}

Please note that where the full-text provided on Manchester Research Explorer is the Author Accepted Manuscript or Proof version this may differ from the final Published version. If citing, it is advised that you check and use the publisher's definitive version.

\section{General rights}

Copyright and moral rights for the publications made accessible in the Research Explorer are retained by the authors and/or other copyright owners and it is a condition of accessing publications that users recognise and abide by the legal requirements associated with these rights.

\section{Takedown policy}

If you believe that this document breaches copyright please refer to the University of Manchester's Takedown Procedures [http://man.ac.uk/04Y6Bo] or contact uml.scholarlycommunications@manchester.ac.uk providing relevant details, so we can investigate your claim.

\section{OPEN ACCESS}




\title{
Economic and political inclusion in human development conditional income transfer programmes in Latin America
}

\begin{abstract}
Most countries in Latin America have implemented human development conditional income transfer programmes to address intergenerational persistence of poverty. Typically, these programmes provide income transfers to households in poverty, conditional on children attending school and on household members attending health clinics. Evaluations have established programmes reach their explicit short- and mediumterm objectives, especially as regards nutrition, children's schooling and improved health care utilisation. It is too early to say whether they will be successful in reducing the intergenerational persistence of poverty. Crucially, this will depend on whether they contribute to the economic and political inclusion of groups in poverty. This article reviews the available literature and finds that participation in human development income transfer programmes leads to improvements in productive capacity but favourable labour market conditions will be needed to guarantee economic inclusion. Improved political participation associated with programme participation raises the prospects for greater political inclusion.
\end{abstract}

Keywords: Conditional Cash Transfers, CCT, Latin America, poverty, economic inclusion, political inclusion.

Armando Barrientos is Professor and Research Director of the Brooks World Poverty Institute, The University of Manchester, UK.

Juan M. Villa is Research Fellow at the Brooks World Poverty Institute, The University of Manchester, UK

\section{Acknowledgements}

The authors are grateful for valuable comments from participants at the Development Studies Association 2013 Conference at the University of Birmingham and at the Conference on The Transformation of Latin American Social Policy at the University of Bath, November 2014. 


\section{Economic and political inclusion in human development conditional income transfer programmes in Latin America}

\section{Introduction}

Most countries in Latin America have adopted large-scale income transfer programmes as a means to address the intergenerational persistence of poverty. Estimations indicate that there are nearly 215 million people participating in these antipoverty interventions in the region (Nino-Zarazua 2011). Conventionally known as conditional cash transfers or ccts, they have attracted considerable attention from international organisations. In the paper we refer to these programmes as human development income transfer programmes because this title provides a more accurate description of their design and orientation. Typically, programmes provide regular and reliable transfers in cash to supplement the income of households in poverty, conditional on children attending school and on household members attending health clinics (Fiszbein and Schady 2009). Their objective is to raise children's human development by facilitating investment in children's education and health. Often, they have evolved into flagship antipoverty programmes leading national antipoverty strategies (Cecchini and Madariaga 2011). A growing literature has emerged assessing their orientation, design and implementation. Rigorous impact evaluations have established that programmes reach their explicit objectives, especially as regards nutrition, children's schooling and improved health care utilisation (Skoufias 2005). While this evidence is consistent with short-term programme objectives, it is too early to say whether human development programmes transfers will prove successful in reducing the intergenerational persistence of poverty in the region (González de la Rocha and Escobar 2012). To a crucial extent, this will depend on whether they contribute to sustained improvements in the productive capacity of programme participants, sufficient to ensure fuller economic inclusion, and whether they provide a break from longstanding clientelistic practices in the region and support the political inclusion of disadvantage groups (Hall 2008; Mahon 2009). The main objective of this paper is to examine the extent to which participation in human 
development transfer programmes can be expected to deliver economic and political inclusion in Latin America. ${ }^{1}$

The persistence of poverty raises important questions about the long run effectiveness of human development conditional income transfers. In Latin America poverty and extreme poverty have declined since the turn of the century. There is consensus on the significant contribution of transfers to this declining trend (see Figure 1). However significant levels of extreme and persistent poverty remain. Are human development conditional income transfer programmes likely to deliver longer terms improvements in human development sufficient to break intergenerational poverty persistence? Are they likely to contribute to the political participation of low income and informal groups? This paper throws light on these two issues, central to the sustainability of human development conditional income transfer programmes, but which have not received adequate attention in the literature. The paper reviews research on the effects of human development income transfer programmes on human capital ${ }^{2}$ and on labour market outcomes for participating children and adults. 3It also reviews the available evidence on the effects of these programmes on the political participation and political inclusion of participant households.

[Figure 1 about here]

Research findings on these two issues, economic and political inclusion, have important implications for the future of antipoverty policy in Latin America and elsewhere. There are direct implications for the design and implementation of these programmes. Increasingly, human development conditional income transfer programmes in the region are perceived as flagship programmes organising and integrating a range of complementary interventions, including interventions linked to employment and enterprise development. Pioneer programmes, like Mexico’s Progresa/Oportunidades (recently renamed Prospera) have developed interventions aimed at facilitating the transition to employment for early cohorts of children who have completed the schooling cycle. There are also broader implications for the study of antipoverty policy 
(Barrientos 2013a). Among them, the need to see human development conditional income transfer programmes as institution building and not as time limited 'development' interventions, stands out. The success and political sustainability of antipoverty policy rests as much on social contract renewal as in the more technical design features of specific programmes.

This paper is divided by four sections. Section 2 will consider what we know about the longer term effects of participation in human development conditional income transfer programmes. Section 3 assesses the short and longer term effects on political participation. A final section draws out the main conclusions.

\section{Do transfers have long term effects on economic inclusion?}

In their initial incarnation, human development conditional income transfer programmes in Latin America were intended to have a limited time window. These programmes were initially set up to support beneficiaries temporarily until the economy could return to positive growth, as actually happened with PANES programme in Uruguay. Initially at least, anti-poverty programmes emerged as a counter-cyclical strategy for poor households. The incidence of dysfunctional but rational responses by households in poverty, taking children off school or 'economising' in health and food items, became evident during the economic crisis of the second half of the 1990s (Cutler et al. 2000). The programmes were expected to help ensure households experiencing poverty avoided disinvesting in their children's human capital. Their time window extended originally to three years in Mexico's 1997 Progresa. Colombia's 2002 Familias en Acción adopted a similar time window. Red de Protección Social in Nicaragua operated from 2000 to 2006 and it was phased out due to the end of its funding cycle. However, contrary to the expectations of policy makers, most human development conditional income transfer programmes are still in operation. In fact, governments in the region have sustained and scaled up cash transfers for longer than it had been intended. 
Table 1 provides summary information on human development conditional income transfers in Latin America and the Caribbean. In most countries, these programmes have become the flagship of antipoverty strategies, and have acquired a firm and stable institutional base in Ministries of Social Development.

[Table 1 about here]

Addressing structural poverty with short-term interventions?

A mismatch existed between policy-makers perceived need to address the short-term impact of the economic crises, and the fact that the programmes de facto targeted structural poverty. While policy makers were focused on responses to a temporary economic turmoil expected to fade out within 3 or 5 years, the programmes were designed to achieve the reduction and eventual eradication of persistent poverty. Introducing Chile Solidario in 2002, President Lagos stated that its aim was to eradicate extreme poverty by 2010. This innovative programme included a support cycle expected to support households for two years, in which beneficiaries could achieve a minimum living standard (MIDEPLAN 2009). Yet the targeting methods in use by a majority of programmes were designed to respond to the structural causes and consequences of poverty or deprivation. In Mexico, the selection of beneficiaries relied on a proxy mean test detecting deficits on a broad set of human, physical and social capitals (Coady and Parker 2009). The persistence of poverty has, in fact, ensured continued demand for such interventions, beyond the short term response to the very regular crises in Latin America.

Human development conditional income transfers have been designed with the dual objective of alleviating current poverty levels and increasing children's human capital. Their rationale is based on an expectation that participating children will reach adulthood equipped with higher productive capacity, enabling them to avoid poverty when forming new households. Human development conditional income transfers focus at the same time on adults and children, but the long-term effects experienced by these groups must be analysed 
differently. Adult household member can use the additional income to enhance their consumption levels and as working capital in activities with very low productivity. ${ }^{4}$ The human capital that adults can accumulate from income transfer is limited, as they commonly engage in informal jobs or end up as self-employed. As regards children, their accumulation of human capital can be traced before they join the labour market, but the long-term effects of these programmes can be observed directly only when they become economically active. Human capital accumulation marks a path to economic inclusion.

\section{Evidence from differential exposure}

While there is scarce direct evidence on the long-term effects of human development conditional income transfers, some studies have assessed different levels of exposure by beneficiaries to these interventions in order to identify medium and longer-term effects. Behrman et al. (2004) evaluate the performance of Mexico's Oportunidades for different levels of exposure comparing programme outcomes in early and late entry municipalities. They show that the longer the exposure to the programme, the greater the effects on years of education. Higher levels of human capital translated into an increase of 25.2 percent in the average wage of working girls, while there were no significant outcomes for boys. Similarly, Barham et al. (2013) estimate the effects of the Red de Proteccion Social in Nicaragua for those beneficiaries that were exposed to the programme for three years a decade ago. As the Red de Proteccion Social was phased out in 2009, they traced ex-participants around the country in order to reduce attrition rates. The focus of this research on Nicaragua's human development conditional income transfer was on the education attainment of children enrolled at 9-12 years old. The results indicate that children who participated in the programme accumulated 0.5 additional school grades and performed better in most of the standardised test scores in maths and language. Barham et al. (2013) were mainly interested in the schooling of former participants, they do not provide evidence on the achievements of children (now adults) on the labour markets. 
Familias en Accion in Colombia has been operating since 2001 inspired by the early success of Oportunidades in Mexico. It began enrolling nearly 200,000 households in 2001 and was scaled up to reach almost three million (with seven million children) in 2010. The programme evaluation found short-term positive effects on education and nutrition of children (Attanasio and Di Maro 2005). After more than a decade of operation, the programme agency studied outcomes for different levels of exposure in order to learn about the long-term effects of the programme on the first cohort of beneficiaries. ${ }^{5}$ A study reported that $9-12$ years old children that had been exposed to the nutrition transfer with mandatory health check-ups were 0.213 standard deviations taller than peers in the control group (Econometría, 2012). The long-term exposure to the programme also brought adverse effects (commonly known as side effects). The share of overweight children in rural areas increased by 5.6 percentage points. Adverse effects were also found in education. Current 18-26 years old youths that had participated when children were 4 percentage points more likely to repeat a school year.

\section{Labour market effects}

The hypothesis that children are expected to perform better than their parents in the labour markets when adults, was tested by the long-term impact evaluation of Familias en Accion. The initial analysis had shown that the program did not appear to have effects on a variety of non-monetary poverty indicators, including the unsatisfied basic needs and the multi-dimensional poverty index. As regards children, the report indicated that treatment and control groups of 18-26 years old youths, were experiencing unemployment rates close to 50 percent with sharp gender differences (unemployment affected 60 percent for women and 10 percent for men at 26 years of age) (Econometría, 2012). The estimates showed that only women were able to obtain high quality jobs, with an increase of 2.5 percentage points in the probability of being hired by a formal employer. Women who participated in the programme reported on average one fewer child compared to non-participants. This facilitated their labour market participation. A qualitative analysis of the labour performance of youths showed that they faced limited labour market opportunities. Despite higher levels of human capital, conditions in the labour market played a determining role in their potential success in breaking the intergenerational transmission of poverty. 
Freije and Rodríguez-Oreggia (2012) studied the short, medium and long-term effects of human development conditional income transfers on the performance of youths on the labour markets in Mexico. They focused their analysis on wages and the probability of being employed as the main outcomes attributable to the Oportunidades programme. The levels of exposure were defined as short participation period for less than three years, medium for 3-6 years, and long for 6 years and longer. For longer levels of exposure, these authors found an increase in the probability of being employed. They acknowledged that the observed increases in the probabilities of being employed was not solely attributable to Oportunidades, but found that the effects of the programme on education were driving this outcome. As for labour incomes, they detected a long-term increase of 12.6 and 14.6 percent in wages for youths with primary and secondary education, respectively, in comparison to the control group. In the medium term, the effects of the programme on wages turned out to be negative for all education levels. The study identified considerable heterogeneity in the effects, but the authors conclude that overall the programme did not provide the children with the means to obtain better jobs (formal and better remunerated) than their parents. In their view, the long-term participation in the programme did not reduce the intergenerational transmission of monetary poverty. Despite the strong evidence on the improvement in the human capital of participant children attributable to human development conditional income transfers, their mixed labour market outcomes raises questions regarding whether these programmes are effective in facilitating the economic inclusion of participating households.

As regards adults, research has shown that adult household members marginally increase their labour participation, with stronger effects on males (Alzúa et al. 2010). Females show more success in finding better quality jobs. Barrientos and Villa (2015) studied the labour market outcomes of Familias en Acción, concluding that the human development conditional income transfers caused a 7.1 percentage points increase in the proportion of employed women with health insurance. They also detected a sharp increase of 10 percentage points in the labour participation of single mothers living with young children. These effects emerged from differentiating subgroups of participants (single mothers, types of household composition), suggesting 
heterogeneity in labour market effects. Although participation improves labour market outcomes for some, these effects disappear when considering the overall population. Findings on whether these programmes are capable of generating improved economic opportunities for beneficiary households are very mixed.

In summary, human development conditional income transfer programmes originally emerged as countercyclical instruments supporting households experiencing poverty during crises, but they also had a focus on structural poverty. Over time, they have been scaled up and institutionalised, extending their time window. This raised the potential for longer-term effects on poverty and labour outcomes. This applies to adults and children participants, and especially for beneficiaries that were enrolled when children and became adults. There is limited knowledge on these effects. The evidence emerging from studies is mixed. Children's improved human capital does not necessarily translate into better labour market outcomes. Labour market outcomes among adults show heterogeneity, but improvements in employment and access to formal jobs are relatively small. Favourable labour market conditions are also required for the programmes to be effective in the longer-term.

\section{Do transfers generate political participation?}

The literature on the politics of the welfare state has long noted that policies influence politics (Pierson 1993). The presence, reach, and design of social policies contribute to shaping public opinion and political support, with implications for the sustainability and evolution of such policies. By contrast, welfare institutions in Latin America, and other developing regions show very weak path dependence (Barrientos 2009). Weak stratification effects of welfare institutions in Latin America provide a possible explanation. For the region as a whole, social insurance institutions covered, at best, formal sector workers, thus excluding large sections of the population. In the 21 st century, most governments in the region have implemented or expanded social assistance programmes and policies with a view to integrating hitherto excluded groups within social protection systems. The nature and modality of this incorporation has implications for the strength of stratification effects (Barrientos 2014; Ferreira and Robalino 2010). 
Against this background, the issue whether participation of low income groups in large-scale human development conditional income transfer programmes has implications for their political inclusion - and through associated stratification effects for the sustainability of emerging social assistance institutions becomes highly significant. This section explores the findings from the scarce literature on this issue. ${ }^{6}$ Transfer programmes and short term political effects

There is consensus around the view that large-scale transfer programmes can have observable electoral effects in the short term. This is common ground for a broad range of views on the desirability of transfer programmes. Hall relies on media reports to articulate a concern that Bolsa Familia might come to be understood as a successful tool to ensure electoral success in the short run, thus obviating the need to address structural reforms. As he puts it, "there is a risk that the imperative to make short term electoral gains could compromise longer-term investment in key areas such as education, health and sanitation” (Hall 2008: 816). Zucco makes the obvious point that from "the strictly political standpoint, large scale cash distribution to the poor is a formidable short run strategy" (Zucco 2008: 46).

As regards short term political effects, research has focused on assessing whether who benefits from these effects and the extent to which incumbents can and do influence the direction of these effects. There is some agreement around the view that incumbents are most likely to benefit from short term effects of transfer programmes. Manacorda et al. (2011) find that beneficiaries of PANES in Uruguay are more likely to vote in support of the incumbent than non-participants. The extent to which politicians at different levels of government are able to draw electoral credit from the programme depends on their participation in the implementation of the programme (De Janvry et al. 2010; Zimmermann 2012). Linos (2013) finds for Honduras that participation in cash transfer programmes had a statistically significant effect on the probability of incumbent re-election in municipal elections but not in presidential elections. 
There is much less agreement on the extent to which the allocation of programme places, or budgets, is an important factor in garnering electoral support for incumbents. The issue here is that voting in poorer areas with higher incidence of transfers is also more likely to vote for pro-poor coalitions, independently of the distribution of the transfers. Nupia (2011) examines the distribution of Familias en Acción participants across municipalities in Colombia and finds that it matches incumbents core voter areas in presidential elections. Giovagnoli (2005) studies the distribution of Argentina's Jefes $y$ Jefas and finds that the distribution of transfer receipt is correlated with municipalities with Peronist incumbents, but that this correlation could alternatively be explained by the socio-economic conditions at municipal level. Fried (2012) considered the allocation of places and budgets to municipalities under Bolsa Familia in the 2008 elections and finds that political machines do not explain the distribution of the programme across municipalities in Brazil, but that socio-economic variables do. Also on Bolsa Familia, Bohn (2011) analyses support for Lula in elections going back to 1989 and concludes that the pattern of support for him was in place prior to the introduction of the programme in 2003. ${ }^{7}$ The main conclusions from these studies is that whilst short effects of transfer programmes on the electoral support for incumbents can be observed and measured, these do not necessarily reflect politically motivated allocation of the programme. As Fried concludes, there is "little evidence that political criteria explain variation in the coverage of Bolsa Familia across municipalities..." (Fried, 2012: 1049).

Transfers and long-term political effects

For our purposes, the issue whether human development conditional income transfer programmes have longterm political effects is particularly important. The study on Uruguay's PANES referred to above finds that programme participants are more likely to vote in support of incumbents who implement a large-scale antipoverty transfer programme. In the short term, this can be interpreted as pocketbook voting. The issue is whether antipoverty policies, and human development conditional income transfer programmes specifically, can sustain political support in the medium and longer term. Mahon raises precisely this issue with a paper entitled "Can new social programs bring about a new period of political incorporation in Latin America?" As he puts it: with the introduction of "conditional transfer programs, the state are not structuring a civil society relationship and its presence is not constant but contingent. People do not become its beneficiaries by becoming members of anything... it is quite likely 
that the political loyalties created by these programs will be relatively shallow, limited to voting patterns, and even at that, potentially mobile... will beneficiaries of social protection and conditional transfers turn out be poor defenders of democratic rules" (Mahon 2009: 7).

Mahon's prior regarding the role of civil society organisations in the expansion of social protection is in line with the development of social insurance in the region, initially through trade unions in key sectors establishing social insurance funds, later consolidated into publicly supported and run funds. By contrast, participation in social assistance programmes is not membership based. Yet this is precisely their strength, because they are grounded on a citizenship principle, as opposed to the contribution principle which underlies social insurance. Incorporation through social assistance needs different reference points (Barrientos 2013b). Interestingly, the study by Linos (2013) referred to above distinguishes direct transfers to households; community grants, and a mixed mode. She finds that community grants and the mix of transfers and community grants, where membership is required, did not have statistically significant effects on the reelection of incumbents.

What about participation in political processes. In Colombia’s Familias en Acción, Baez et al. (2012) use match individual data across programme and electoral participation. They find that programme participants are 1.5 to 2.5 percentage points more likely to be registered than non-participants. Among registered voters, the probability that they have registered subsequent to the programme being implemented in the municipality is 3 percentage points. Programme participants are also 7-9 percentage points more likely to vote than nonparticipants. Findings on registration and participation effects are important because they indicate longer term political inclusion. In most programmes, registration is a requirement to secure personal identity cards, leading to improvement in electoral registration of low income groups. De la O (2013) studies electoral outcomes using evaluation data for Oportunidades in Mexico matched with municipal level electoral data. Exploiting the quasi experimental evaluation process in Oportunidades which enables a comparison of eligible households incorporated into the programme at different times for administrative reasons, she finds that early 
programme participants show a 5 percentage point higher probability of turning out to vote than nonparticipating, but equally eligible, households (from a 60\% baseline). In both Colombia and Mexico the higher turnout favoured incumbents.

The growing institutionalisation of human development conditional income transfer programmes suggests that incorporation of low income groups is not a simply short term strategy. The process of institutionalisation has been slow and uncertain at times. As discussed in the previous section, in many countries in the region, human development conditional income transfer programmes were introduced as short term development interventions, Mexico's Oportunidades or Colombia's Familias en Acción, for example. In Brazil, Bolsa Escola evolved from municipal innovation to a federal programme from 1995 to 2001. The creation of Ministries of Social Development to formulate and implement antipoverty programmes and policies, often around flagship human development conditional income transfer programmes, is also an indication of the permanence of these programmes (Cecchini and Martínez 2011).

The interesting point is whether human development conditional income transfer programmes advance more inclusive social contracts. The expansion of social policy in Brazil, and which includes human development conditional income transfers, is on a path of development that begins with the new 1988 Constitution and the recognition of the right to social protection (Britto and Soares 2011; Jaccoud et al. 2010). The reform and expansion of non-contributory pension pensions and the emergence of human development conditional income transfers from municipal activism can be understood as being located on this path. However, the available literature on other Latin American countries on the role of social policy and these programmes in supporting a renewed social contract is scarce.

In summary, the fast growing literature on the political effects of human development conditional income transfers agrees on the point that the programmes have moderate short term effects on electoral outcomes, in the main through increased support for incumbents. The electoral effects cannot be interpreted as clientelistic 
practices which have been prevalent in the region. There is very limited research on the longer term effects of transfers; but two studies conclude that human development conditional income transfers have resulted in increased registration and voting turnout among low income groups. It is therefore too early to assess whether cash transfers have facilitated a greater political inclusion of these groups, but the findings from this growing literature point in this direction.

\section{Conclusion}

This paper aimed to throw light on two questions: Are human development conditional income transfer programmes likely to deliver longer terms improvements in human development sufficient to break intergenerational poverty persistence? Are they likely to contribute to the political participation of low income and informal groups? Inevitably, the answers to these questions must be work in progress, as a full assessment of these effects can only materialise in the fullness of time.

In answering the first question, it is important to distinguish the impact on adults from the impact on children. Improvements in the human development of children following participation in human development conditional income transfers are expected to raise their productive capacity and facilitate permanent exit from poverty. Studies focusing on human capital accumulation of participant children generally find the expected impact. Whether this is reflected in improved labour market outcomes depends to an important extent on labour market conditions. Improvements in the human capital of children cannot guarantee improved labour market opportunities, but generate improved outcomes when conditions are positive. As regards adults, the observed impact of human development conditional transfers on labour market participation and outcomes is relatively small, and can be positive or negative. The positive effects can be observed more clearly for specific groups, like single mothers in Colombia. It is too early to say whether the introduction of complementary active labour market policies can strengthen positive effects. 
The bulk of the research on the political effects of human development conditional income transfers has focused on short-term electoral effects. These appear to support incumbents, but not in the 'clientelist' mould which featured strongly in the region in the past. The short-term electoral effects can be interpreted instead as increasing political support for pro-poor governing coalitions. Conditions might have helped secure political support from the better off, who might have grasped their social investment dimension (Zucco 2014). Evidence on the longer-term effects of human development conditional income transfers on political participation is scarce. Improvements in the electoral registration and turnout of low income groups have been confirmed in only two countries; in part because researchers have not examined this issues elsewhere. Raising the political inclusion of disadvantaged groups does point to positive longer term effects of these programmes.

Research on human development conditional income transfers is growing apace. The scant literature on their longer-term effects is in part explained by their relatively recent introduction in the region. The potential for longer-term effects depends on the extent to which these programmes generate economic and political inclusion. Reviewing the available literature provides reasons for optimism, but further research on this issue is urgently needed. 


\section{Notes}

\footnotetext{
${ }^{1}$ Economic and political inclusion are key dimensions of social inclusion understood as the terms on which people participate in society.

${ }^{2}$ Human capital describes the knowledge, skills, and assets of individuals capable of enhancing their productivity.

${ }^{3}$ The discussion in the paper relies largely, but not exclusively, on impact evaluation studies of human development conditional income transfer programmes.

${ }^{4}$ A long-term evaluation found that parents would invest part of the transfer in productive assets, increasing their income in about 10 percent (Gertler et al. 2012).

${ }^{5}$ For details on the long-term effects of Familias en Accion on education outcomes see Baéz and Camacho (2011).

${ }^{6}$ The influence of political factors on the adoption of social assistance programmes is a related but distinct question. Readers interested in this issue should (Borges Sugiyama 2011; Carnes and Mares 2010).

${ }^{7}$ See also Zucco and Power (2013).
} 


\section{References}

Alzúa, M. L., Cruces, G. and Ripani, L. (2010) Welfare programs and labour supply in developing countries. Experimental evidence for Latin America, CEDLAS-UNLP.

Attanasio, O. and Di Maro, V. (2005) 'Efectos de mediano plazo del Programa Oportunidades sobre el consumo en áreas rurales', in B. Hernández and M. Hernández (eds). Evaluación Externa de Impacto del Programa Oportunidades 2004: Aspectos Económicos y Sociales. Instituto Nacional de Salud Pública, pp. 17-52.

Baez, J. E. and Camacho, A. (2011) Assessing the long-term effects of conditional cash transfers on human capital : evidence from Colombia, The World Bank.

Baez, J. E., Camacho, A., Conover, E. and Zárate, R. A. (2012) Conditional cash transfers, political participation, and voting behavior, The World Bank.

Barham, T., Macours, K. and Maluccio, J. A. (2013) More Schooling and More Learning?: Effects of a ThreeYear Conditional Cash Transfer Program in Nicaragua after 10 Years, Inter-American Development Bank.

Barrientos, A. (2009) 'Labour markets and the (hyphenated) welfare regime in Latin America', Economy and Society 38(1): 87-108.

Barrientos, A. (2013a) Social Assistance in Developing Countries, Cambridge: Cambridge University Press.

Barrientos, A. (2013b) 'The Rise of Social Assistance in Brazil', Development and Change 44(44): 4.

Barrientos, A. (2014) 'On the distributional implications of social protection reforms in Latin America', in G. A. Cornia (ed.). Falling Inequality in Latin America: Policy Changes and Lessons. Oxford: Oxford University Press.

Barrientos, A. and Villa, J. M. (2015) 'Antipoverty transfers and labour force participation effects', Journal of Development Studies.

Behrman, J. R., Cheng, Y. and Todd, P. (2004) 'Evaluating pre-school programs when length of exposure to the program varies: A non-parametric approach', Review of Economics and Statistics 86(1): 108-132.

Bohn, S. (2011) 'Social policy and vote in Brazil: Bolsa Familia and the shifts in Lula's electoral base', Latin American Research Review 46(1): 54-79.

Borges Sugiyama, N. (2011) 'The difussion of Conditional Cash Transfer programs in the Americas', Global Social Policy 11(2-3): 250-278.

Britto, T. and Soares, F. V. (2011) Bolsa Família and the Ctizen’s Basic Income: A Misstep?, International Policy Centre for Inclusive Growth.

Carnes, M. and Mares, I. (2010) Deindustrialization and the rise of non-contributory social programs in Latin America, Georgetown University.

Cecchini, S. and Madariaga, A. (2011) Conditional cash transfer programmes. The recent experience in Latin America and the Caribbean, ECLAC. 
Cecchini, S. and Martínez, R. (2011) Protección social inclusiva en América Latina: Una mirada integral, un enfoque de derechos, Santiago: CEPAL.

Chen, S. and Ravallion, M. (2012) More Relatively-Poor People in a Less Absolutely Poor World, The World Bank.

Coady, D. and Parker, S. (2009) Targeting Social Transfers to the Poor in Mexico, International Monetary Fund.

Cutler, D. M., Knaul, F., Lozano, R., Méndez, O. and Zurita, B. (2000) Financial Crisis, health outcomes and aging: Mexico in the 1980s and 1990s, National Bureau of Economic Research.

De Janvry, A., Finan, F. and Sadoulet, E. (2010) Local Electoral Incentives and Decentralized Program Performance, NBER.

De la O, A. L. (2013) 'Do conditional cash transfers affect electoral behaviour? Evidence from a randomized experiment in Mexico', American Journal of Political Science 57(1): 1-14.

Ferreira, F. H. G. and Robalino, D. (2010) Social protection in Latin America. Achievements and limitations, The World Bank.

Fiszbein, A. and Schady, N. (2009) Conditional Cash Transfers. Reducing Present and Future Poverty, Washington DC: The World Bank.

Freije, S. and Rodríguez-Oreggia, E. (2012) Long Term Impact of a Cash-Transfer Program on Labor Outcomes of the Rural Youth in Mexico.

Fried, B. J. (2012) 'Distributive Politics and Conditional Cash Transfers: The Case of Brazil's Bolsa Família', World Development 40(5): 1042-1053.

Gertler, P. J., Martinez, S. W. and Rubio-Codina, M. (2012) 'Investing Cash Transfers to Raise Long-Term Living Standards', American Economic Journal: Applied Economics 4(1): 164-192.

Giovagnoli, P. (2005) Poverty Alleviation or Political Networking? A combined qual-quant analysis of the implementation of safety nets in post crisis Argentina, DESTIN, London School of Economics.

González de la Rocha, M. and Escobar, A. L. (2012) Pobreza, transferencias condicionadas y sociedad, Mexico City: CIESAS.

Hall, A. (2008) 'Brazil’s Bolsa Família: A Double-Edged Sword?’, Development and Change 39(5): 799-822.

Jaccoud, L., Hadjab, P. D. E.-M. and Chaibub, J. R. (2010) The consolidation of social assistance in Brazil and its challenges, 1988-2008, International Policy Centre.

Linos, E. (2013) 'Do conditional cash transfer programmes shift votes? Evidence from the Honduran PRAF', Electoral Studies online.

Mahon, J. E. (2009) Can new social programs bring about a new period of political incorporation in Latin America?, Williams College.

Manacorda, M., Miguel, E. and Vigorito, A. (2011) 'Government transfers and political support', Amercan Economic Journal: Applied Economics 3: 1-28. 
MIDEPLAN (2009) Fundamentos para la Operación de un Sistema Intersectorial de Protección Social, Secretaría Ejecutiva del Sistema de Protección Social.

Nino-Zarazua, M. (2011) Mexico's Progresa-Oportunidades and the emergence of Social Assistance in Latin America, BWPI, The University of Manchester, available at http://ideas.repec.org/p/bwp/bwppap/14211.html (accessed10 July 2014).

Nupia, O. (2011) Anti-poverty programs and presidential election outcomes: Familias en Acciòn in Colombia, Universidad de los Andes Facultad de Economìa.

Paes-Sousa, R., Regalia, F., \& Stampini, M. (2013). Conditions for success in implementing CCT programs: Lessons for Asia from Latin America. Policy Brief No. IDB-PB-192. Washington D.C.: InterAmerican Development Bank.

Pierson, P. (1993) 'When effect becomes cause: Policy feedback and political change', World Politics 45(4): 595-628.

Skoufias, E. (2005) Progresa and Its Impacts on the Welfare of Rural Households in Mexico, International Food Policy Research Institute.

Zimmermann, L. (2012) Jai Ho? The impact of a large public works programme on the Government's election performance in India, University of Michigan.

Zucco, C. (2008) 'The President's “New” Constituency: Lula and the Pragmatic Vote in Brazil's 2006 Presidential Elections', Journal of Latin American Studies 40: 29-49.

Zucco, C. and Power, T. (2013) 'Bolsa Família and the shift in Lula's Electoral Base, 2002-2006: A reply to Bohn', Latin American Research Review 48(2): 3-24.

Zucco, C. (2014). Conditionality and support for redistributive transfers: Results from observational and survey-experimental studies. Mimeo. Sao Paulo: FGV. 
Table 1: Human development conditional income transfers in Latin America and the Caribbean circa 2010.

\begin{tabular}{llrr}
\hline \multicolumn{1}{c}{ Country } & \multicolumn{1}{c}{ Programme } & Beneficiaries & \multicolumn{1}{c}{ Units } \\
\hline Argentina & Asignación Universal por Hijo & $1,480,000$ & Households \\
Bolivia & Bono Madre Niño & 355,328 & Mothers \\
Bolivia & Bono Juancito Pinto & $1,925,000$ & Children \\
Brazil & Bolsa Família & $13,872,243$ & Households \\
Chile & Chile Solidario* & 250,000 & Households \\
Colombia & Familias en Acción & $2,083,315$ & Households \\
Costa Rica & Avancemos & 150,000 & Children \\
Dom. Rep & Solidaridad & 623,000 & Households \\
Ecuador & Bono de Desarrollo Humano & $1,900,000$ & People \\
El Salvador & Comunidades Solidarias (former Red Solidaria) & 350,000 & Households \\
Guatemala & Mi Familia Progresa & 350,000 & Households \\
Honduras & PRAF & 345,000 & Households \\
Jamaica & Programme of Advancement through Health and Education & 130,000 & Households \\
Mexico & Oportunidades & $5,845,056$ & Households \\
Nicaragua & RPS* & 30,000 & Households \\
Panama & Red de Oportunidades & 72,471 & Households \\
Paraguay & Tekopora & 498,628 & People \\
Peru & Juntos & 649,553 & Households \\
\hline
\end{tabular}

* Ended programmes. Source: Authors and Paes-Sousa et al. (2013). 
Figure 1

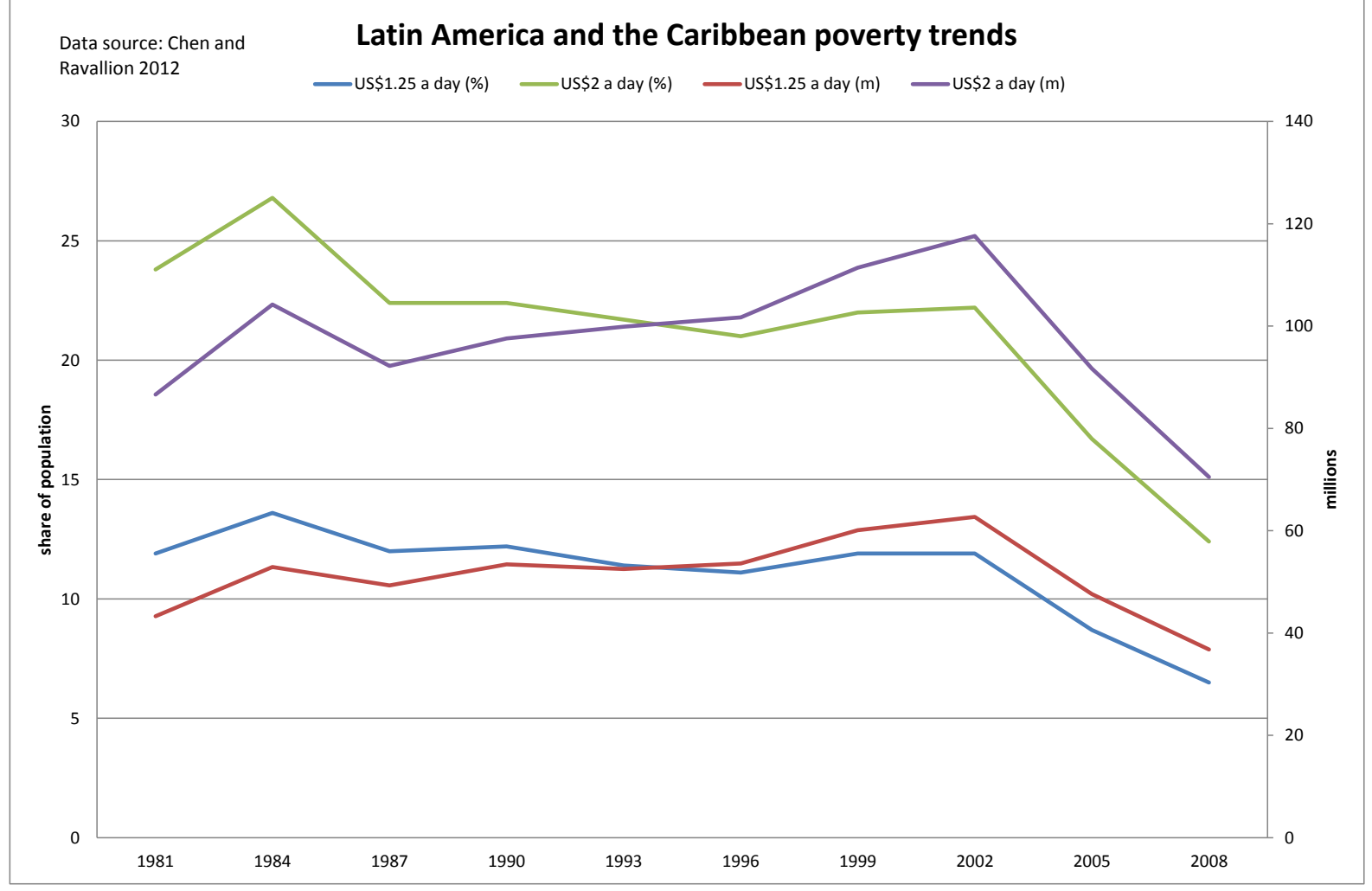

